\title{
CAN ORGANIC FARMING HELP TO REDUCE NATIONAL ENERGY CONSUMPTION AND EMISSIONS OF GREENHOUSE GASSES IN DENMARK?
}

\author{
by \\ TOMMY DALGAARD, \\ Danish Institute of Agricultural Sciences \\ Dept. of Agricultural Systems \\ P.O. Box 50, DK-8830 Tjele, Denmark \\ NIELS HALBERG \\ Danish Institute of Agricultural Sciences \\ Dept. of Agricultural Systems \\ P.O. Box 50, DK-8830 Tjele, Denmark \\ and \\ JES FENGER \\ National Environmental Research Institute \\ Dept. of Atmospheric Environment \\ P.O. Box 358, DK-Roskilde, Denmark.
}

\author{
Kluwer Academic Publishers \\ Boston/Dordrecht/London
}




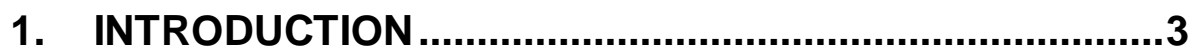

2. MATERIALS AND METHODS ........................................5

2.1 Scenarios for $100 \%$ Conversion to Organic Farming in Denmark .......5

2.2 Simulation of Fossil Energy Use.................................................6

IPCC's greenhouse gas inventories...................................................... 7

3. RESULTS.............................................................

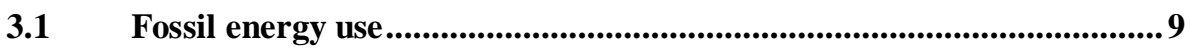

Emissions of Greenhouse Gases ................................................ 11

4. DISCUSSION ........................................................13

5. CONCLUSIONS ...........................................................15

6. ACKNOWLEDGEMENTS ..............................................16

7. REFERENCES ................................................................16 


\begin{abstract}
Methods to investigate whether organic farming might help to reduce energy consumption and greenhouse gas emissions are needed. The aim of this study is for the first to present an upscaling procedure, where an existing farm level energy consumption model, in combination with the Intergovernmental Panel on Climate Change's guidelines, is used to calculate agricultural energy consumption and greenhouse gas emissions on the national level. Secondly, this procedure is used to simulate scenarios for conversion to organic farming in Denmark. Three scenarios for conversion to organic farming with the present crop yield and an expected improved future crop yield are compared to the 1996-situation in Denmark, where conventional farming dominates. In all scenarios, fossil energy use and emissions of the three major agricultural greenhouse gases carbon dioxide, methane and nitrous oxide are reduced. The highest reduction in the net energy use (49-51\%) is found in a scenario (A) with $100 \%$ fodder self-sufficiency and reduced livestock production, while the lowest reduction (10-16\%) is found in a scenario (C), with the same animal production as in 1996. The average energy use per fodder unit in the organic crop production (1.4-1.5 MJ/fodder unit) and livestock production (18-24 MJ/livestock unit), was lower than in the 1996-situation (2.5 MJ/fodder unit, and $30 \mathrm{MJ} /$ livestock unit). However, total production was also lower in the organic scenarios, which furthermore had different compositions, with lower potentials for future bio-energy production.
\end{abstract}

Keywords Fossil energy, Greenhouse gas, Upscaling methodology, Organic farming, Carbon dioxide, Methane, Nitrous oxide, Agroecology, Bio-energy.

Acronyms SFU - Scandinavian Feed Units; LSU - Livestock Units; EF Emission Factor; CF - Correction Factor.

\title{
1. INTRODUCTION
}

The first aim of this paper is to present an upscaling procedure, where an existing farm level model for energy use (Dalgaard et al. 2001), in combination with existing methods to calculate agricultural emissions of greenhouse gasses (IPCC 2000), is used to calculate national level energy consumption and greenhouse gas emissions. The second aim is to use this procedure to simulate three scenarios for conversion to $100 \%$ organic farming in Denmark and by comparison to the 1996 situation to answer the question "Can organic farming help to reduce national energy consumption and emissions of greenhouse gasses in Denmark?" 
There are three main reasons to limit the use of fossil energy. First, fossil energy is a limited resource which, as far as possible, should be conserved for the coming generations (Brown et al. 1998). Second, combustion of fossil energy leads to classical pollution via compounds of sulphur and nitrogen, which damage the environment via acidification, eutrophication etc. (Illerup et al. 1999). Finally, combustion results in emissions of the greenhouse gas carbon dioxide $\left(\mathrm{CO}_{2}\right)$. This gas is responsible for most of the anthopogenic changes in the earth-atmosphere energy balance, which may lead to global climate changes (IPCC 1997).

As a result of the Rio-conference in 1992 and the Kyoto Protocol in 1997, industrialised countries are committed to reduce their greenhouse gas emissions. Here not only carbon dioxide from energy use counts but also nitrous oxide and methane, which to a large extent are of organic origin. One method to reduce greenhouse gas emissions is to change agricultural production. In Denmark, the agricultural sector currently is responsible for about $12 \%$ of the total contribution to the greenhouse effect (Fenger et al. 1990), and changes in agricultural greenhouse gas emissions therefore matters. Farm level studies have identified large potentials for reductions of the fossil energy use from conversion to organic farming (Dalgaard et al. 2001). However, there are no well-described national level methods to calculate consequences for energy use and greenhouse gas emissions following conversion to organic farming (Halberg et al. 2000). Moreover, the existing reference manuals for calculation of national emissions of greenhouse gases (IPCC 1997, 2000) give some guidelines, but do not distinguish $\mathrm{CO}_{2}$-emissions from agriculture from emissions from other sectors, and cannot be readily adapted to investigate scenarios for changes in agricultural production systems. However, the reference manuals can more readily be used for the calculation of emissions of the two other important greenhouse gases relating to agricultural production; nitrous oxide $\left(\mathrm{N}_{2} \mathrm{O}\right)$ and methane $\left(\mathrm{CH}_{4}\right)$.

The present chapter focuses on national scenario calculations of energy consumption and greenhouse gas emissions based on agronomic model calculations. However, the results must be seen in a broader sustainability context, and can for instance be combined with economic calculations where the costs and benefits in relation to these externalities are estimated. The possibilities for such inter-disciplinary interactions are discussed at the end of this paper. 


\section{MATERIALS AND METHODS}

\subsection{Scenarios for $100 \%$ Conversion to Organic Farming in Denmark}

In 1998, the Danish Government requested an inter-disciplinary review of the consequences of phasing out pesticides. One of the resulting reports (Bichel Committee 1999) concerned conversion to $100 \%$ organic farming in Denmark and the resulting ban on the use of both pesticides and synthetic fertilisers. In this study, the following three theoretical scenarios for $100 \%$ conversion to organic farming within a thirty-year time horizon are considered (Alrøe et al. 1998):

A) Full national self-sufficiency with fodder (i.e. no import). This particularly limits the pig production, because it was assumed that the total Danish milk quota would still be produced after conversion.

B) $15 \%$ import of fodder for ruminants and $25 \%$ import for nonruminants. Here the pig production is limited too, but less than in scenario A.

C) The same level of animal production after conversion as in 1996 (unlimited import of fodder).

In this paper, crop production on the $2.7 \times 10^{6}$ ha agricultural area of Denmark is simplified to consist of grass/clover, cereals, row crops and permanent grass. For each crop type, the yield is estimated in SFU's ${ }^{1}$ for the present practice on organic Danish farms (Halberg and Kristensen 1997), and for an expected improved future practice (Table 1).

Table 1. Estimated Danish crop yields (102 SFU/ha), and in brackets the crop distribution on the agricultural area (106 ha). After Alrøe et al. (1998).

\begin{tabular}{l|c|cc}
\hline & $\begin{array}{c}\text { Conventional } \\
\text { agriculture } \\
1996\end{array}$ & \multicolumn{2}{c}{ Organic Scenarios A, B and C } \\
\hline Grass/clover & $65(0.3)$ & $52(1.0)$ & improved yield \\
Cereals & $50(1.6)$ & $34(1.3)$ & $39(1.0)$ \\
Row Crops & $104(0.4)$ & $97(0.2)$ & $97(0.2)$ \\
Permanent Grass & $20(0.4)$ & $18(0.2)$ & $18(0.2)$ \\
\hline
\end{tabular}

\footnotetext{
${ }^{1} 1$ Scandinavian Fodder unit $(\mathrm{SFU})=12.5 \mathrm{MJ}$ barley equivalent, metabolisable energy

21 Livestock Unit (LSU) corresponded in 1996 to 1 cow of large breed, 3 sows or 30 porkers produced
} 
For example, the potential for yield improvements in organic cereals and grass/clover are expected to be $15 \%$ and $10 \%$. From this the corresponding livestock production in LSU's ${ }^{3}$, and fodder import is estimated (Table 2).

Table 2. Total Danish crop production, fodder import and animal production.

\begin{tabular}{ll|c|ccc}
\hline & Conventional & \multicolumn{3}{|c}{ Organic Scenarios } \\
\cline { 3 - 5 } & & agriculture & \multicolumn{3}{|c}{ present (improved) crop yields } \\
& 1996 & A & B & C \\
\hline Crop production & $10^{9} \mathrm{SFU}$ & 15 & $12(13)$ & $12(13)$ & $12(13)$ \\
Fodder import & $10^{9} \mathrm{SFU}$ & 4 & $0(0)$ & $2(3)$ & $4(3)$ \\
Livestock units & $10^{6} \mathrm{LSU}$ & 2.3 & $1.7(1.7)$ & $2.1(2.3)$ & $2.4(2.4)$ \\
\hline
\end{tabular}

\subsection{Simulation of Fossil Energy Use}

For each crop type the average, national fossil energy use is simulated with Dalgaard et al.'s (2001) model (Table 3 and 4). This model can simulate fossil energy use for the most common crops in Denmark for different management practices, transport distances, soil types etc. The model includes both direct and indirect (embedded) energy use and a set of standard values for energy use in keeping livestock. In this paper, average national energy use for the crop types is calculated as weighted averages for the crops grown on loamy soil, sandy soil, and irrigated sandy soil. The distribution of Danish soils by area is 39\% loamy soils, $10 \%$ irrigated soils, and $51 \%$ non-irrigated sandy soils. Grass/clover is defined as $50 \%$ grass/clover pasture and 50\% grass/clover silage.

Table 3. Average Danish energy use for conventionally grown crop types.

\begin{tabular}{lcccc}
\hline $10^{6} \mathrm{~J} / \mathrm{ha}$ & Grass/clover & Cereals & Row Crops & Perm. grass \\
\hline Oil $^{\mathrm{a}}$ & 3.1 & 4.5 & 13.2 & 0.8 \\
Electricity $^{\mathrm{b}}$ & 0.8 & 0.9 & 0.4 & 0.0 \\
Fertilisers $^{\mathrm{c}}$ & 10.3 & 5.9 & 4.3 & 0.7 \\
Machinery & 1.0 & 1.4 & 4.0 & 0.3 \\
\hline Total & 15.2 & 12.7 & 21.9 & 1.8 \\
\hline
\end{tabular}

${ }^{a}$ Diesel, petrol, lubricants etc., incl. refining and distribution, ${ }^{b}$ Irrigation and drying. ${ }^{c}$ Fertilisers, pesticides and lime.

Cereals are defined as 50\% winter cereals and 50\% spring cereals, including energy use for both grain and straw harvest. Row crops are defined as fodder beets, and permanent grassland is defined as grass/clover pasture

\footnotetext{
3 Livestock Unit (LSU) corresponded in 1996 to 1 cow of large breed, 3 sows or 30 porkers produced

6
} 
on non-irrigated sandy soil. For comparison, the metabolisable energy in the produced crops can be calculated using norms (Strudsholm et al. 1997), and compared to the fossil energy use.

Table 4. Average, Danish energy use for organic grown crop types with present yields, and with improved yields expected in the future (in brackets).

\begin{tabular}{lcccc}
\hline $10^{6} \mathrm{~J} /$ ha & Grass/clover & Cereals & Row Crops & Perm. grass \\
\hline Oil $^{\mathrm{a}}$ & $2.4(2.6)$ & $4.3(4.3)$ & $11.3(11.6)$ & $0.8(0.8)$ \\
Electricity $^{\mathrm{b}}$ & $0.8(0.8)$ & $0.7(0.8)$ & $0.5(0.5)$ & $0.0(0.0)$ \\
Fertilisers $^{\mathrm{c}}$ & $0.0(0.0)$ & $0.0(0.0)$ & $0.0(0.0)$ & $0.0(0.0)$ \\
Machinery & $0.7(0.8)$ & $1.3(1.3)$ & $3.4(3.5)$ & $0.3(0.3)$ \\
\hline Total & $4.0(4.2)$ & $6.3(6.4)$ & $15.2(15.6)$ & $1.1(1.1)$ \\
\hline
\end{tabular}

${ }^{a}$ Diesel, gasoline, lubricants etc., incl. refining and distribution, $b$ Irrigation and drying. $c$ Fertilisers, pesticides and lime

Given the energy use for crop production, the number of animals produced, and the needed fodder import, the total national energy use can be estimated (Dalgaard 2000). For the 1996-situation, the calculated energy use for each type of energy source (SI) can be compared with the energy use according to official statistics (ST), and a correction factor $(\mathrm{CF}=\mathrm{ST} / \mathrm{SI})$ can be calculated (Table 8). These CF-values are then used to correct the simulated values of energy use in the scenarios for conversion to organic farming.

Finally, the net energy production from crop residues and biogas is added to get the national agricultural energy balance. For the 1996-situation, production values from national statistics are used (13.7 PJ from straw combustion, and 0.5 PJ biogas from slurry, Danish Energy Agency 1997). In the organic scenarios, it is assumed that no energy production takes place, because all the straw is needed for deep bedding in the stables, and mining of carbon in the form of biogas from slurry is perceived undesirable.

\subsection{IPCC's greenhouse gas inventories}

The $\mathrm{CO}_{2}$-emission for each fossil fuel is estimated from Equation 1, where $\mathrm{C}$ is \% carbon in the fuel, $\mathrm{M}_{\mathrm{CO} 2}$ is the molecular weight of $\mathrm{CO}_{2}=44$ $\mathrm{g} / \mathrm{mole}, \mathrm{B}_{\mathrm{t}}$ is the lower combustion value for the fuel, and $\mathrm{M}_{\mathrm{c}}$ is the molecular weight of $\mathrm{C}=12 \mathrm{~g} / \mathrm{mole}$. From this, $\mathrm{CO}_{2}$-emission factors for the most common fuels and input factors in agriculture are calculated (Table 5). The $\mathrm{CO}_{2}$-emission from biofuels is set to zero, and emissions related to indirect energy input like machinery and fertilisers are set to the emission from the energy source, from which these are primarily produced (The European Commission 1997). 


$$
\mathrm{CO}_{2}-\text { emission }=\frac{\mathrm{C}_{\times} \mathrm{M}_{\mathrm{cO} 2} \times 10}{\mathrm{~B}_{\mathrm{t}} \times \mathrm{M}_{\mathrm{c}}}
$$

Table 5. Examples of $\mathrm{CO}_{2}$-emission factors.

\begin{tabular}{lc}
\hline & $\mathrm{CO}_{2}$-emission factor $\left(\mathrm{kg} \mathrm{CO}_{2} / 10^{9} \mathrm{~J}\right)$ \\
\hline Coal & 95.0 \\
Diesel oil & 74.0 \\
Natural gas & 56.9 \\
Biofuels (biogas and straw) & 0.0 \\
\hline Electricity & 95.0 \\
Machinery & 95.0 \\
Synthetic fertilisers & 56.9 \\
Concentrates & 74.0 \\
\hline
\end{tabular}

All the $\mathrm{CH}_{4}$-emissions from Danish agriculture are presumed to come from livestock. For each animal type, the $\mathrm{CH}_{4}$-emission is calculated as the sum of the standard emissions (EF) ${ }^{4}$ from the animal and the related manure production (Equation 2, IPCC 1997).

$$
\mathrm{CH}_{4}-\text { emision }=\mathrm{EF}_{\text {animal }}+\mathrm{EF}_{\text {manure }}
$$

Finally, the $\mathrm{N}_{2} \mathrm{O}$-emission is calculated as the sum of direct and indirect emissions (Equations 3-5). The emission factors $\mathrm{EF}_{1}=0.0125 \mathrm{~kg}$ $\mathrm{N}_{2} \mathrm{O}-\mathrm{N} / \mathrm{kg} \mathrm{N}$-input is for the direct emission from the soil, $\mathrm{EF}_{2}=5 \mathrm{~kg} \mathrm{~N}_{2} \mathrm{O}-$ $\mathrm{N} / \mathrm{ha} / \mathrm{yr}$ is for the mineralisation of organic soils, and $\mathrm{EF}_{3}=0.0114 \mathrm{~kg} \mathrm{~N}_{2} \mathrm{O}$ $\mathrm{N} / \mathrm{kg} \mathrm{N}$ is for animal production facilities (stables and pastures). $\mathrm{F}_{\mathrm{OS}}$ is the area of organic soils (histosols) in rotation. $\mathrm{F}_{\mathrm{AW}}$ is manure- $\mathrm{N}$ handled, corrected for non $\mathrm{N}_{2} \mathrm{O}-\mathrm{N}$-emissions in the form of e.g. $\mathrm{NH}_{3}$ or $\mathrm{NO}_{\mathrm{x}}$, and the $\mathrm{N}$ produced at pasture. $\mathrm{F}_{\mathrm{AP}}$ is manure- $\mathrm{N}$ ex animal. $\mathrm{F}_{\mathrm{BN}}$ is $\mathrm{N}$ fixed from the atmosphere by legumes $(\mathrm{kg} \mathrm{N} / \mathrm{yr}) . \mathrm{F}_{\mathrm{CR}}$ is crop residues returned to the soil $(\mathrm{kg} \mathrm{N} / \mathrm{yr}) . \mathrm{F}_{\mathrm{SN}}$ is the synthetic fertiliser-N (kg N/yr) used. $\mathrm{M}_{\mathrm{N}}$ and $\mathrm{M}_{\mathrm{N} 20}$ are the molecular weights for nitrogen and nitrous oxide. The indirect $\mathrm{N}_{2} \mathrm{O}$ emission includes $\mathrm{N}_{2} \mathrm{O}$ produced from the atmospheric deposition of $\mathrm{NO}_{2}$ and $\mathrm{NH}_{3}$ volatilised from spread fertilisers $\left(\mathrm{N}_{\mathrm{GAS}}\right)$, and $\mathrm{N}_{2} \mathrm{O}$ produced from the $\mathrm{N}$, which is leached from agricultural soils $\left(\mathrm{N}_{\mathrm{LEACH}}\right) . \mathrm{EF}_{4}=0,01 \mathrm{~kg}$ $\mathrm{N}_{2} \mathrm{O} / \mathrm{N}$-gas and $\mathrm{EF}_{5}=0.025 \mathrm{~kg} \mathrm{~N}_{2} \mathrm{O}-\mathrm{N} / \mathrm{N}$-leached are standard emission factors (IPCC 1997). Both $\mathrm{CH}_{4}$ and $\mathrm{N}_{2} \mathrm{O}$ emissions are converted to $\mathrm{CO}_{2^{-}}$

\footnotetext{
${ }^{4}$ Standard EF-values for cool regions (mean annual temperature $<15^{\circ} \mathrm{C}$ ) are used.
} 
equivalents by multiplication of their global warming potentials for a 100 year time-horizon: 21 and 310 (Fenger and Kilde 1994).

$$
\begin{gathered}
\mathrm{N}_{2} \mathrm{O}-\text { emision }=\mathrm{N}_{2} \mathrm{O}_{\text {direct }}+\mathrm{N}_{2} \mathrm{O}_{\text {indirect }} \\
\mathrm{N}_{2} \mathrm{O}_{\text {direct }}=\frac{2 \times \mathrm{M}_{\mathrm{N}}}{\mathrm{M}_{\mathrm{N} 2 \mathrm{O}}} \times\left[\left(\left(\mathrm{F}_{\mathrm{SN}}+\mathrm{F}_{\mathrm{AW}}+\mathrm{F}_{\mathrm{BN}}+\mathrm{F}_{\mathrm{CR}}\right) \times \mathrm{EF}_{1}\right)+\mathrm{F}_{\mathrm{OS}} \times \mathrm{EF}_{2}+\mathrm{F}_{\mathrm{AP}} \times \mathrm{EF}_{3}\right] \\
\mathrm{N}_{2} \mathrm{O}_{\text {indirect }}=\frac{2 \times \mathrm{M}_{\mathrm{N}}}{\mathrm{M}_{\mathrm{N} 2 \mathrm{O}}} \times\left(\mathrm{N}_{\mathrm{GAS}} \times \mathrm{EF}_{4}+\mathrm{N}_{\mathrm{LEACH}} \times \mathrm{EF}_{5}\right)
\end{gathered}
$$

\section{RESULTS}

\subsection{Fossil energy use}

The national 1996-energy use for the defined crop and animal types are simulated and distributed over energy sources (Table 6 and Table 7). Thereafter, the simulated values (SI) are, in line with Dalgaard et al. 2001, compared to statistics (ST), and a correction factor $(\mathrm{CF}=\mathrm{ST} / \mathrm{SI})$ for each energy source is calculated (Table 8).

Table 6. Calculated Danish energy use $\left(10^{15} \mathrm{~J}\right)$ for the 1996 crop production.

\begin{tabular}{lcrcc|r}
\hline & Grass/clover & Cereals & Fodder Beet & Perm. grass & Total \\
\hline Oil & 1.0 & 8.2 & 6.8 & 0.4 & 16.3 \\
Electricity & 0.2 & 1.4 & 0.2 & 0.0 & 1.8 \\
Fertilisers $^{\text {a }}$ & 2.8 & 9.5 & 1.9 & 0.3 & 14.5 \\
Machinery & 0.3 & 2.2 & 1.8 & 0.1 & 4.4 \\
\hline Total & 4.2 & 21.4 & 10.7 & 0.7 & 37.0 \\
\hline
\end{tabular}

${ }^{\mathrm{a})}$ Incl. pesticides

The same procedure is used to calculate the energy use for crop and livestock production in the organic scenarios. However, since no statistics are available for the future scenarios, the CF-factors calculated for the 1996situation (Table 8) are used to correct the SI-values of the organic scenarios. From these figures, total national agricultural energy balances are produced (Table 9). In these balances, energy use for production of fodder is accounted for under crop production. 
Table 7. Calculated Danish energy use $\left(10^{15} \mathrm{~J}\right)$ for the 1996 animal production.

\begin{tabular}{lcc|c}
\hline & Cattle & Pigs and Poultry & Total \\
\hline Electricity in stables & 7.3 & 3.3 & 10.7 \\
Oil for heating stables & 0.0 & 1.7 & 1.7 \\
Buildings, inventory etc. & 3.2 & 2.5 & 5.7 \\
Fodder Import $^{\text {Own fodder production }}{ }^{\text {a }}$ & 7.0 & 13.0 & 20.0 \\
\hline Total & 16.2 & 14.8 & 30.0 \\
\hline a & 33.8 & 35.3 & 69.0 \\
\hline
\end{tabular}

$\left.{ }^{a}\right)$ The part of energy for crop production (Table 6), which is not exported

Table 8. Simulated total energy use for agricultural production in Denmark 1996 compared to national statistics (Dalgaard et al. 2001).

\begin{tabular}{lccc}
\hline & \multicolumn{2}{c}{ PJ fossil energy } & \multirow{2}{*}{$\begin{array}{c}\text { Correction-factor } \\
(\mathrm{CF}=\mathrm{ST} / \mathrm{SI})\end{array}$} \\
\cline { 2 - 3 } Direct energy use & Simulated (SI) & Statistics (ST) ${ }^{\mathrm{a}}$ & 1.1 \\
$\quad$ Fuels & 18.0 & 19.3 & 1.0 \\
$\quad$ Electricity & 12.5 & 12.7 & 1.0 \\
\hline Indirect energy use & 14.5 & 13.9 & 1.1 \\
$\quad$ Fertilisers, & & & 1.1 \\
pesticides etc. & 4.4 & 4.6 & 1.0 \\
Machinery & 5.7 & 6.3 & \\
$\quad$ Buildings & 20.0 & 20.0 & \\
$\quad$ Import of fodder & 75.1 & 76.8 & \\
\hline Total energy use & & & \\
\hline
\end{tabular}

Table 9. Total Danish agricultural energy balance $\left(10^{15} \mathrm{~J}\right)$ for the 1996-situation and for the three organic scenarios with respectively the present and (in parenthesis) improved yields.

\begin{tabular}{l|c|rrr}
\hline & \multirow{2}{*}{$\begin{array}{c}\text { Danish } \\
\text { agriculture }\end{array}$} & \multicolumn{3}{|c}{ Organic Scenarios } \\
\cline { 3 - 5 } & 1996 & A & \multicolumn{2}{|c}{ present (improved) crop yields } \\
\hline Crop production & 38 & $18(18)$ & $18(18)$ & $18(18)$ \\
Livestock production & 39 & $13(14)$ & $28(31)$ & $40(34)$ \\
\hline Total & 77 & $31(32)$ & $45(50)$ & $57(53)$ \\
Energy production & 14 & $0(0)$ & $0(0)$ & $0(0)$ \\
\hline Net energy use & 63 & $31(32)$ & $45(50)$ & $57(53)$ \\
\hline
\end{tabular}

The results show that the total net energy use in all the organic scenarios would be lower than the 1996-energy use. However, the energy use should also be compared to the production, which is higher in the 1996situation Table 2). Finally, energy efficiencies, expressed as the fossil energy use per produced fodder and livestock unit, are calculated (Table 10). 


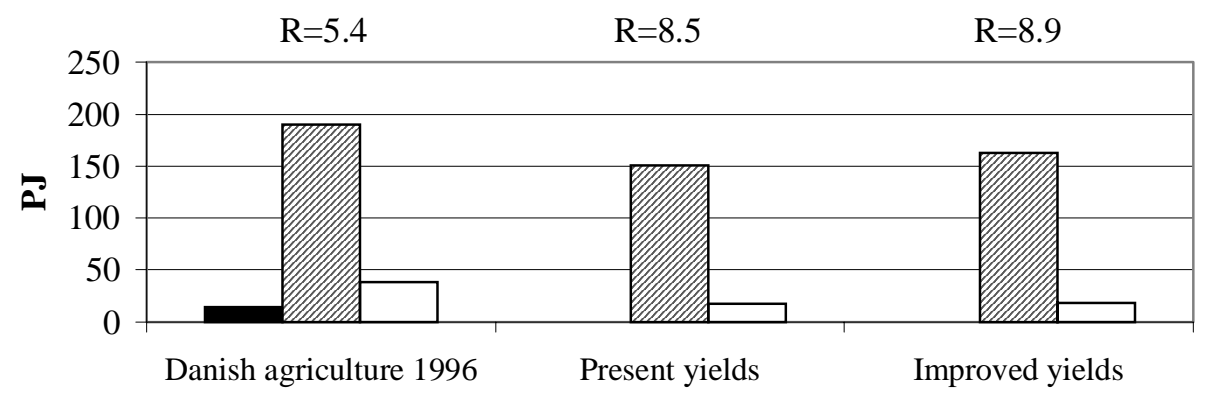

Energy Production, biofuels

Metabolisable energy in crop production

$\square$ Fossil energy use for crop production

Figure 1. The bio-fuel energy and the metabolisable energy in the crops produced compared to the fossil energy use for crop production in 1996, and in the two organic scenarios with the same animal production (Scenario C: unlimited fodder import). $\mathrm{R}$ is the ratio between energy production and energy use. $\left(1 \mathrm{PJ}=10^{15} \mathrm{~J}\right)$.

Table 10. Average Danish energy use per produced fodder- and livestock unit (1 MJ=10 $\mathrm{J}$ ).

\begin{tabular}{l|c|rrr}
\hline & Danish & \multicolumn{3}{|c}{ Organic Scenarios } \\
\cline { 3 - 5 } & agriculture & \multicolumn{2}{|c}{ present (improved) crop yields } \\
& 1996 & A & B & C \\
\hline Crop prod. (MJ/SFU) & 2.5 & $1.5(1.4)$ & $1.5(1.4)$ & $1.5(1.4)$ \\
Livestock prod. (MJ/LSU) & 30 & $18(18)$ & $21(21)$ & $24(21)$ \\
\hline
\end{tabular}

\subsection{Emissions of Greenhouse Gases}

Emission of $\mathrm{CO}_{2}$ is calculated from the accounted energy use and does not include storage in soils or emissions from soils and agricultural crop burning. The reason for this is that these effects are too uncertain to include in the scenarios, and that conversion to organic farming will only result in minor changes (Dalgaard et al. 2000). The $\mathrm{CH}_{4}$-emission is calculated from the number of animals (Table 11) and $\mathrm{N}_{2} \mathrm{O}$-emission from estimated direct and indirect contributions (Table 12). 
Table 11. Example: calculation of the $1996 \mathrm{CH}_{4}$-emission.

\begin{tabular}{lcccc}
\hline & & \multicolumn{3}{c}{$\mathrm{CH}_{4}$-emission $\left(10^{9} \mathrm{~kg}\right)$} \\
\cline { 3 - 5 } & $10^{5}$ animals & from animals & from manure & Total \\
\hline Dairy cows & 8.3 & 99 & 12 & 111 \\
Heifers & 9.1 & 44 & 5 & 49 \\
Bullocks & 5.8 & 28 & 3 & 31 \\
Sows & 10.1 & 2 & 3 & 5 \\
Other pigs & 52.8 & 8 & 16 & 24 \\
Hens & 55.0 & 0 & 1 & 1 \\
\hline Total & \multicolumn{5}{c}{}
\end{tabular}

Table 12. Example: calculation of the $1996 \mathrm{~N}_{2} \mathrm{O}$-emission.

\begin{tabular}{|c|c|c|c|}
\hline & & $\begin{array}{c}\text { Emission } \\
\left(10^{6} \mathrm{~kg} \mathrm{~N} \mathrm{yr}^{-1}\right)\end{array}$ & $\begin{array}{c}\text { Total } \\
\left(10^{6} \mathrm{~kg} \mathrm{~N}_{2} \mathrm{O}\right)\end{array}$ \\
\hline \multicolumn{4}{|l|}{ Direct emission $\left(\mathbf{N}_{2} \mathbf{O}_{\text {direct }}\right)$} \\
\hline Synthetic nitrogen & $\mathrm{F}_{\mathrm{SN}}$ & 292 & 5.7 \\
\hline Animal waste handling & $\mathrm{F}_{\mathrm{AW}}$ & 131 & 2.6 \\
\hline Animal production & $\mathrm{F}_{\mathrm{AP}}$ & 222 & 4.0 \\
\hline Legumenous fixations & $\mathrm{F}_{\mathrm{BN}}$ & 138 & 2.7 \\
\hline Crop residues & $\mathrm{F}_{\mathrm{CR}}$ & 331 & 6.5 \\
\hline Organic soils (ha area) & $\mathrm{F}_{\mathrm{OS}}$ & 18440 & 0.1 \\
\hline \multicolumn{4}{|l|}{ Indirect emission $\left(\mathrm{N}_{2} \mathrm{O}_{\text {indirect }}\right)$} \\
\hline Deposited gas from fertilisers & $\mathrm{N}_{\mathrm{GAS}}$ & 103 & 1.6 \\
\hline Leaching & $\mathrm{N}_{\text {LEACH }}$ & 198 & 7.8 \\
\hline Total & & & 31.0 \\
\hline
\end{tabular}

Subsequently, the emissions of greenhouse gases can be converted to $\mathrm{CO}_{2}$-equivalents (Figure 2). The methane emissions are not significantly reduced in the organic scenarios because the productions of ruminants are sustained. In contrast, the nitrous oxide emissions are reduced, primarily because no mineral fertilisers are used in the scenarios for conversion to organic farming, and because emissions from crop residues and N-leaching decay. 


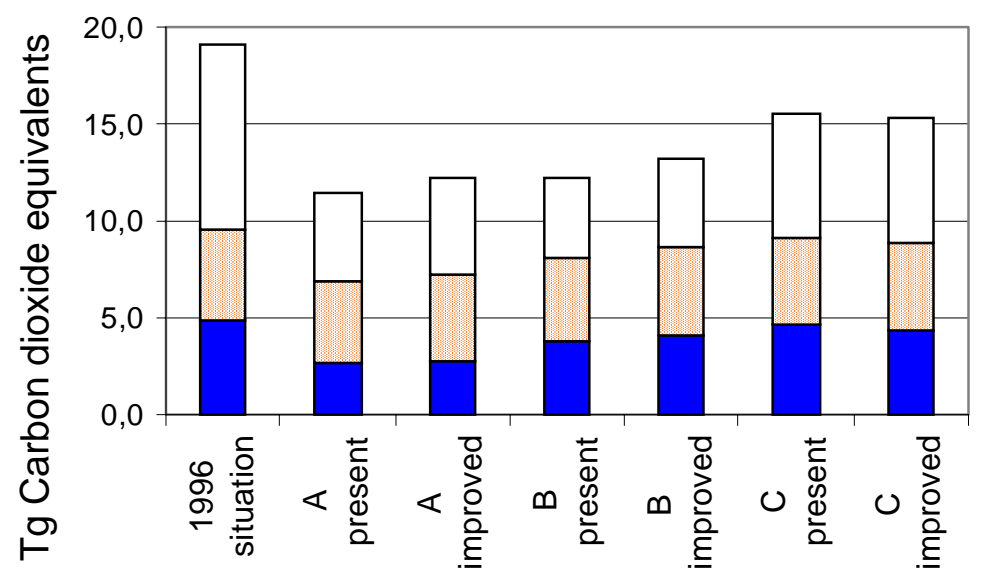

\section{- Carbon dioxide $\quad \square$ Methane $\quad \square$ Nitrous oxide}

Figure 2. Total national agricultural emissions of greenhouse gases $\left(1 \mathrm{Tg}=10^{9} \mathrm{~kg}\right)$.

\section{DISCUSSION}

The calculations show that a conversion to $100 \%$ organic farming in Denmark may result in a reduced fossil energy use and reduced emissions of the three most important greenhouse gases. However, the vegetable and animal production would also be lower in the organic scenarios. Therefore, for example, the total energy use for crop production would be reduced by $52-53 \%$, while the energy use per fodder unit would be reduced by only $40-$ $44 \%$.

The presented benefits in the form of lower energy consumption and greenhouse gas emissions from conversion to organic farming must be compared to the costs of such conversion. The macro-economic consequences of conversion to $100 \%$ organic farming is extremely difficult to estimate, partly because of the expected major changes in marked prices following the much higher market share of organic products after full conversion and partly because of the uncertainties in estimation of the costs in organic compared to conventional production. If the organic product prices after 100\% conversion would equal the present, conventional product prices, Jacobsen and Frandsen (1999) estimated a reduction in the total Danish Gross Domestic Product of 
$1-3 \%$ and a reduction of the private consumption between $2-5 \%$. However, if consumer preferences result in higher future prices on organic products the overall costs for the society would be lower.

In the 1996-situation, there is a potential to double the production of bio-energy in the form of straw and biogas (Dalgaard et al. 2000). This potential is not as large in the organic scenarios, where straw production is lower, and more straw is needed for the deep bedding stables, required for animal welfare reasons. If the conventional biomass potential was fully utilised, another $14 \times 10^{15} \mathrm{~J}$ bioenergy could be produced. If this energy was deducted from the 1996 energy use no energy would be saved by conversion to $100 \%$ organic farming. Furthermore, there was an export of $2 \times 10^{9} \mathrm{~kg}$ grain in the 1996-situation. If these cereals were burned in power plants for heat and electricity, a gross energy production of about $30 \times 10^{15} \mathrm{~J}$ may be achieved. In this situation, the conventional farming of 1996 has a more positive energy balance than any of the scenarios for conversion to organic farming. However, there are many unanswered questions concerning the possibilities for combined food energy systems (Kuemmel et al. 1998), which may change the conclusions of this paper. Further investigations within this area are therefore recommended.

The comparison of simulated energy use with official statistics showed a good prediction of the 1996-situation. The calculated CFs from 1996 were therefore also used to correct the simulation results in the organic scenarios. This linear scaling procedure was the best procedure within the limits of the present work, but future work can possibly improve the methods for upscaling and the possibility to test simulated, national scale results considerably. One reason why the "true" CF for the organic scenarios might differ from the 1996-CF is the different field size distribution on the organic farms. This becomes important because the known non-linear relation between field size and energy use (Nielsen and Sørensen 1994) is not included in Dalgaard et al.'s (2001) model. Another reason is that the marked for organic products is effected by the scale to which the conversion happens. Conversion of one farm will not effect the marked but a $100 \%$ conversion of the whole country will, as discussed above, change both the prices of agricultural products and the demand for fodder and energy dramatically (Jacobsen and Frandsen 1999). To assess such scale effects, simple aritmethic aggregation might not be sufficient. Consequently, new procedures to scale up farm level information on energy use and emissions of greenhouse gases to the regional and national level are needed.

In this study, the default IPCC (1997) methodology for calculation of methane and nitrous oxide emissions is applied to scenarios where the Danish agricultural production was described in highly aggregated livestock 14 
and crop type groups. However, the calculated emissions in the 1996situation were similar to the values of a more detailed study of emissions from Danish agriculture in 1995 (Andersen 1999). Consequently, it seems that our scenario resolution is sufficient to get reliable results for greenhouse gas emissions.

The total greenhouse gas emissions are not surprisingly lowest in the scenario with the highest fodder self-sufficiency and the lowest animal production (A), while the highest emissions found are where the animal production and the fodder import is high $(\mathrm{C})$. In the scenarios $\mathrm{A}$ and $\mathrm{B}$, the greenhouse gas emissions are increased when the crop yields are improved, while the opposite is the case in scenario $\mathrm{C}$. The cause for this is, that the animal production in scenario A and B are limited by the total crop yield. Therefore, higher yields lead to a higher animal production and higher greenhouse gas emission. On the contrary, in scenario $\mathrm{C}$, the animal production is not limited by the crop yield, because import of fodder sustains an animal production equal to the one in 1996. Therefore, higher yields here leads to a lower fodder import, which lower the total greenhouse gas emissions. To validate whether this reverse relationship may be caused by a too high energy cost for imported fodder assumed in Dalgaard et al.'s (2001)

model, a sensitivity analysis is carried out. If for instance the energy cost for imported fodder is reduced by $25 \%$, the difference between the greenhouse gas emissions for present and improved crop yields in scenario $\mathrm{C}$ is reduced by $0.1 \mathrm{Tg}$ carbon dioxide equivalents. However, this reduction is less than the difference described above, and the reduction in total greenhouse gas emissions by increasing the yields do not seem to be caused only by an overestimated energy cost of imported fodder. Similarly, the present scenarios could be used as a basis for economic sensitivity analysis, and the role of prices in input and output choice both on the farm level and with the society as a whole could be analysed.

\section{CONCLUSIONS}

The presented method is useful to calculate national energy consumption and emissions of greenhouse gasses from both conventional and organic farming. However, the method to scale up energy consumption from an existing farm level model to the national level was only possible to validate for conventional farming. Future work on procedures to estimate consequences of conversion to organic farming on larger scales than the farm is therefore needed.

Results showed that $\mathrm{CO}_{2}$ from agricultural energy consumption is responsible for about $1 / 4$ of the greenhouse gas emissions from both conventional and organic agricultural production. In the scenarios for 
conversion to organic farming, the $\mathrm{N}_{2} \mathrm{O}$-emission is particularly reduced, partly because of lower nitrogen losses (Dalgaard et al. 1998). Also for the other two major greenhouse gases, a significant reduction is expected following organic conversion. The net greenhouse gas emission from agriculture may in the future be lowered via increased bio-energy production, and a large unused potential for such bio-energy production is present in conventional agriculture.

In conclusion, conversion to organic farming might help to reduce energy consumption and emissions of greenhouse gasses in Denmark, but for policy analysis these reductions must be evaluated also with other criteria for a sustainable future agricultural production.

\section{ACKNOWLEDGEMENTS}

We would like to thank professor John R. Porter, The Royal Veterinary and Agricultural University in Copenhagen, and Senior Researcher Nick Hutchings, Danish Institute of Agricultural Sciences for valuable comments on this paper. Further, we thank Carolien Kroeze, Department of Environmental Sciences, Wageningen University and Johnny M. Andersen, The National Environmental Institute of Denmark for information about the application of the IPCC method. Finally, we thank Danish Environmental Protection Agency and Danish Research Centre for Organic Farming for sponsoring the initial parts of this work.

\section{REFERENCES}

Alrøe, H.F., Kristensen, E.S., Hansen, B. 1998. Danmarks samlede produktion og indsats af hjalpestoffer (The total Danish production and use of input factors). Report A.1.1. Background report for the inter-disciplinary Bichel Committee group on organic farming. Danish Environmental Protection Agency, Copenhagen. 12 p.

Andersen, J. 1999. Estimering af emission af methan og lattergas fra landbruget baseret på IPCC's estimationsmetode (Estimating agricultural methane and nitrous oxide emissions based on the IPCC-method). Working report 116. The National Environmental Institute of Denmark, Roskilde. ISSN 1395-5675. 47 p.

Bichel Committee. 1999. Rapport fra den Tvarfaglige фkologigruppe (Report from the interdiciplinary group on organic farming). Report. Danish Environmental Protection Agency, Copenhagen. ISBN 87-7909-292-6. 98 p.

Brown, L.R., Flavin, C.F., French, H. 1998. State of the World. W.W. Norton, New York. ISBN 0-393-31727-7. $251 \mathrm{p}$.

Dalgaard, T., Halberg, N., Kristensen, I.S. 1998. Can organic farming help to reduce $N$ losses? Experiences from Denmark. Nutrient Cycling in Agroecosystems 52, pp 277-287. 
Dalgaard, T. 2000. Farm Types - How can they be used to structure, model, and generalise farm data? Report 2.00.01, vol. 2:98-114. Agricultural Economics Research Institute (LEI), The Hague. ISBN 90-5242-563-9. 157 p.

Dalgaard, T., Halberg, N., Fenger, J. 2000. Simulation of fossil energy use and emissions of greenhouse gases. FØJO-report no. 5. Danish Research Centre for Organic Farming, Foulum. ISSN: 1398-716X. 70 p.

Dalgaard, T., Halberg, N., Porter, J. 2001. A model for fossil energy use in Danish agriculture used to compare organic and conventional farming. Agriculture, Ecosystems and Environment 87 (1) :pp 51-65.

Danish Energy Agency. 1997. Energy Statistics 1996. Ministry of Environment and Energy, Copenhagen. ISBN 87-7844-065-3. 36 p.

Fenger, J., Fenhann, J., Kilde, N. 1990. Danish Budget for Greenhouse Gases. Nord 1990:97. Nordic Ministry Council, Copenhagen. 116 p.

Fenger, J., Kilde, N.A. 1994. Landbrugets bidrag til drivhuseffekten (Agricultural contributions to the greenhouse effect). Jord og Viden 17: pp 6-7.

Halberg, N., Kristensen, I.S. 1997. Expected crop yield loss when converting to organic dairy farming in Denmark. Biol. Agric. Hort. 14: pp 25-41.

Halberg, N., Kristensen, I., Dalgaard, T. 2000. Linking data sources and models at the levels of processes, farm types and regions. Report 2.00.01, vol. 1: pp 16-30. Agricultural Economics Research Institute (LEI), The Hague. ISBN 90-5242-563-9. 189 p.

Illerup, J.B., Winther, M., Lyck, E., Fenger, J. 1999. Hvor kommer luftforureningen fra? (Where does the air pollution come from?). Theme Report no. 29. National Environmental Research Institute, Roskilde. ISSN 0909-8704 32 p.

IPCC, Intergovernmental Panel on Climate Change. 2000. Good Practice Guidance and Uncertainty Management in National Greenhouse Gas Inventories. Penman, J., Kruger, D., Galbally, I. et al. (eds.). Chp.4. Agriculture. IPCC Technical Support Unit, Kanagawa, Japan.

IPCC, Intergovernmental Panel on Climate Change. 1997. Greenhouse Gas Inventory Reference Manual. Houghton, J.T., et al. (eds.). Vol. 3. IPCC Technical Support Unit, London.

Jacobsen, L. and Frandsen, S. 1999. (Analyse af de samfundsфkonomiske konsekvenser af en omlagning af dansk landbrug til фkologisk produktion (Analysis of the macro-economic consequences of conversion to organic farming in Denmark). Report A. 2.3. Background report for the inter-disciplinary Bichel Committee group on organic farming. Danish Environmental Protection Agency, Copenhagen.

Kuemmel, B., Langer, V., Magid, J., de Neergaard, A., Porter, J.R. 1998. Energetic, economic and ecological balances of a combined food and energy system. Biomass and Bioenergy 15 (4/5). pp 407-416. 
Nielsen, V., Sørensen, K.G. 1994. Green Fields. Operational Analysis and Model Simulations. Report 59. National Institute of Agricultural Engineering, Bygholm. ISBN 877471-040-0. $155 \mathrm{p}$.

Strudsholm, F., Nielsen, E.S., Flye, J.C. et al. 1997. Fodermiddeltabel 1997. Sammensatning og fodervardi affodermidler til kvag. Danish Extension Service. Skejby. 69: pp 1-53

The European Commission. 1997. Harmonisation of environmental life cycle assessment for agriculture. Audsley, E. (eds.) Final Report Concerted Action AIR3-CT94-2028. European Commission DG VI Agriculture, Brussels. 